\title{
Aktivitas Quick On The Draw dalam Tatanan Pembelajaran Kooperatif Ditinjau dari Self Confidence pada Materi Peluang
}

\author{
Siti Maimunah ${ }^{1 *}$, Sri Purwanti Nasution ${ }^{1}$ \\ 1SDN 01 Banjit. Jalan Dr. Ak Gani No 41 Pasar Banjit, Way Kanan 34766, Indonesia. \\ ${ }^{2}$ Universitas Islam Negeri Raden Intan Lampung. Jalan Endro Suratmin, Sukarame, Bandar \\ Lampung 35133, Indonesia. \\ * Corresponding Author. E-mail: sbadarus51@gmail.com
}

Received : 13-07-2018; Revised : 26-07-2018; Accepted : 13-08-2018

\begin{abstract}
Abstrak
Penelitian ini bertujuan untuk mengetahui: pengaruh penerapan aktivitas quick on the draw dalam tatanan pembelajaran kooperatif terhadap hasil belajar peserta didik, apakah terdapat pengaruh antara peserta didik yang memiliki self confidence (tinggi, sedang, rendah) terhadap hasil belajar peserta didik, apakah terdapat interaksi antara aktivitas quick on the draw dalam tatanan pembelajaran kooperatif dengan self confidence terhadap hasil belajar peserta didik. Jenis penelitian ini adalah penelitian quasy experimental design. Desain penelitian yang digunakan adalah posttest only. Pengambilan sampel penelitian menggunakan teknik proportionate stratified random sampling. Pengumpulan data yang digunakan adalah menggunakan metode wawancara, dkomentasi, tes dan angket. Instrumen yang digunakan untuk pengambilan data adalah tes berbentuk uraian essay dan angket berbentuk pernyataanpernyataan. Analisis data menggunakan uji ANAVA dua jalan dengan sel tak sama. Hasil penelitian diperoleh (1) terdapat pengaruh aktivitas quick on the draw dalam tatanan pembelajaran kooperatif terhadap hasil belajar. (2) terdapat pengaruh antara peserta didik yang memiliki self confidence (tinggi, sedang, rendah) terhadap hasil belajar. (3) tidak terdapat interaksi antara aktivitas quick on the draw dalam tatanan pembelajaran kooperatif dengan self confidence terhadap hasil belajar peserta didik.
\end{abstract}

Kata kunci: Aktivitas Quick On The Draw, Pembelajaran Kooperatif, Hasil Belajar, Self Confidence.

\section{Abstract}

This study aims to determine the effect of the application of quick on the draw activities in the cooperative learning order to the learners 'outcomes whether there is influence between learners who have self-confidence (high, moderate, low) to learners' learning outcomes, to determine whether there is interaction between quick on the draw activities in the cooperative learning arrangement with self-confidence towards learners' learning outcomes. This type of research is quasi-experimental design. The research design used was posttest only. The research samples used proportionate stratified random sampling technique. The data collection used was the interview method, documentation, test, and questionnaire. Instruments used for data retrieval are an essayshaped test and questionnaire-shaped statements. Data analysis used a two-way ANOVA test with the unequal cell. The result of the research (1) that there is the influence of quick on the drawing activity in the cooperative learning arrangement to the learning result. (2) that there is influence between learners who have self-confidence (high, medium, low) on learning outcomes. (3) there is no interaction between quick on the draw activities in the cooperative learning order with selfconfidence towards the learners' learning outcomes.

Keywords: Quick On The Draw Activity, Cooperative Learning, Learning Outcomes, Self Confidence

PENDAHULUAN

Salah satu pendidikan yang dapat mengembangkan kemampuan dan kreativitas peserta didik adalah pendidikan matematika (Syafitri et al. 2018). Namun, pembelajaran matematika 
masih dianggap sulit oleh sebagian peserta didik (Fadholi, Waluya, \&Mulyono 2015; Fitri, Helma, \& Syarifuddin 2014; Fitriasari 2017). Sehingga dapat menyebabkan rendahnya hasil belajar peserta didik. Di antara penyebab rendah tingkat keaktifan dan hasil belajar peserta didik salah satunya yaitu faktor eksternal, dimana di dalam faktor eksternal terdapat lingkungan sekolah yang di dalamnya terdapat model pembelajaran (Ika Mardiyanti 2016). Oleh karena itu, pada proses pembelajaran guru diharapkan menggunakan berbagai model pembelajaran, sehingga dapat meningkatkan semangat belajar siswa (Anwar 2016). Berdasarkan alasan itulah maka mendorong peneliti untuk menggunakan aktivitas pembelajaran yang dapat mempermudah peserta didik dalam memahami materi sehingga dapat meningkatkan hasil belajar.

Model pembelajaran yang digunakan dalam penelitian ini berupa aktivitas quick on the draw dalam tatanan pembelajaran kooperatif. Quick on the draw merupakan suatu pembelajaran yang lebih mengedepankan kepada aktivitas dan kerja sama siswa dalam mencari, menjawab dan melaporkan informasi dari berbagai sumber dalam sebuah suasana permainan yang mengarah pada pacuan kelompok melalui aktivitas kerja tim dan kecepatannya dengan tujuan untuk menjadi kelompok pertama yang menyelesaikan satu set pertanyaan (Lestiyaningsih, Hobri, and Indah 2013).

Beberapa penelitian terdahulu menunjukkan bahwa penggunaan quick on the draw pada pembelajaran kooperatif dapat meningkatkan: kemandirian dan hasil belajar; motivasi dan prestasi belajar; melalui pendekatan thinking aloud pair problem solving meningkatkan kemampuan komunikasi dan penalaran matematis; pembelajaran visual thinking disertai aktivitas quick on the draw meningkatkan kemampuan komunikasi matematis; pemecahan masalah; (Virgiantoro 2017; Muthoharoh and Kusmanto 2015; Rosyana and Sari 2015; Ariawan 2016; Ariawan 2017). Berdasarkan pembahasan di atas dapat disimpulkan bahwa perbedaan penelitian ini dengan penelitian sebelumnya yaitu dalam penelitian ini aktivitas quick on the draw yang digunakan ditinjau dari self confidence berpengaruh terhadap hasil belajar siswa.

Selain itu hasil penelitian sebelumnya yang menggunakan pembelajaran kooperatif dan hasil belajar bahwa model pembelajaran kooperatif tipe jigsaw meningkatkan prestasi belajar; tipe STAD berbantuan multimedia pembelajaran; jigsaw; TPS; STAD; group investigation berbasis proyek; TPS dan kemampuan awal, pembelajaran kooperatif dan gaya belajar meningkatkan hasil belajar (Insany 2016; Cahyani, Tegeh, and I Komang Sudarma 2015; Ahriani 2013, Mardiyanti 2016, Sari and Eurika 2016; Aan Lasmanah 2016; Gumay, Kodarsih, and Mulyanto 2016; Silvina 2017; Dewi, Manuaba, and Suniasih 2017). Berdasarkan pembahasan diatas dapat disimpulkan bahwa perbedaan penelitian ini dengan penelitian sebelumnya yaitu dalam penelitian ini model pembelajaran kooperatif yang digunakan tipe quick on the draw yang ditinjau dari self confidence berpengaruh terhadap hasil belajar.

Adapun penelitian sebelumnya yang telah menggunakan self confidence bahwa kemampuan pemahaman matematis; berfikir kritis matematis dan self confidence siswa dapat meningkat melalui model pembelajaran inkuiri terbimbing; model eliciting activities; discovery learning yang ditinjau dari kemampuan awal matematis siswa; kepercayaan diri siswa dapat di bangun pada konsep asam basa melalui pembelajaran ikuiri terbimbing (Purwasih 2015; Amalia, Duskri, and Ahmad 2015; Haeruman, Rahayu, and 
Ambarwati 2017; Islami, Nahadi, and Permanasari 2015). Berdasarkan pembahasan diatas dapat disimpulkan bahwa perbedaan penelitian ini dengan penelitian sebelumnya yaitu dalam penelitian ini self confidence digunakan untuk meninjau model quick on the draw terhadap hasil belajar.

Berdasarkan penelitian yang sudah ada sebelumnya, dalam penelitian ini diterapkan juga aktivitas pembelajaran yang sama yaitu, aktivitas quick on the draw dengan keterbaruan yaitu untuk mengetahui pengaruh hasil belajar yang ditinjau dari self confidence. Dengan tujuan penelitian untuk mengetahui : 1) Pengaruh penerapan aktivitas quick on the draw dalam tatanan pembelajaran kooperatif terhadap hasil belajar; 2) Pengaruh pada peserta didik yang memiliki self confidence terhadap hasil belajar; 3) Interaksi antara model pembelajaran dengan self confidence terhadap hasil belajar.

\section{METODE}

Metode penelitian yang diterapkan adalah penelitian eksperimen. Jenis penelitian yang digunakan adalah penelitian quasy experimental. Desain penelitian yang digunakan adalah posttest only. Pengambilan sampel penelitian menggunakan teknik proportionate stratified random sampling (Sugiyono 2010). Pengumpulan data yang digunakan adalah menggunakan metode wawancara, dokumentasi, tes dan angket. Instrumen yang digunakan untuk pengambilan data adalah tes berbentuk uraian essay dan angket berbentuk pernyataan-pernyataan. Analisis data uji hipotesis dilakukan dengan menggunakan uji ANAVA dua jalan dengan sel tak sama. Adapun prosedur rancangan penelitian disajikan pada Tabel 1.

Tabel 1. Rancangan Penelitian

\begin{tabular}{cccc}
\hline \multicolumn{1}{c}{ Hasil Belajar $\left(\boldsymbol{B}_{\boldsymbol{J}}\right)$} & $\begin{array}{c}\text { Tinggi } \\
\text { Perlakuan }\left(\boldsymbol{A}_{\boldsymbol{i}}\right)\end{array}$ & $\begin{array}{c}\text { Sedang } \\
\left(\boldsymbol{B}_{\mathbf{1}}\right)\end{array}$ & $\begin{array}{c}\text { Rendah } \\
\left(\boldsymbol{B}_{\mathbf{2}}\right)\end{array}$ \\
$\begin{array}{c}\left(\boldsymbol{B}_{\mathbf{3}}\right) \\
\text { Aktivitas Quick On The Draw Dalam Tatanan Pembelajaran }\end{array}$ & $\left(A_{1} B_{1}\right)$ & $\left(A_{1} B_{2}\right)$ & $\left(A_{1} B_{3}\right)$ \\
Kooperatif Ditinjau Dari Self Confidence $\left(\boldsymbol{A}_{\mathbf{1}}\right)$ & & & \\
Model Pembelajaran Konvensional $\left(\boldsymbol{A}_{\mathbf{2}}\right)$ & $\left(A_{2} B_{1}\right)$ & $\left(A_{2} B_{2}\right)$ & $\left(A_{2} B_{3}\right)$ \\
\hline
\end{tabular}

Keterangan :

$A_{i}=$ Perlakuan

$\boldsymbol{B}_{\boldsymbol{j}}=$ Hasil Belajar

$A_{1}=$ Aktivitas quick on the draw dalam tatanan pembelajaran kooperatif ditinjau dari self confidence

$A_{2}=$ Model pembelajaran konvensional

$A_{1} B_{1}=$ Hasil belajar tinggi

$A_{1} B_{2}=$ Hasil belajar sedang

$A_{1} B_{3}=$ Hasil belajar rendah

Sebelum menguji hipotesis, di lakukan terlebih dahulu percobaan atau uji prasyarat, yaitu sebagai berikut:

\section{a. Uji Normalitas}

Uji normalitas data yang digunakan adalah Uji Liliefors dimana Uji Liliefors ini kerap dimanfaatkan untuk memeriksa kenormalan data. Dalam uji Liliefors, rumus yang digunakan adalah sebagai berikut:

$L_{\text {hitung }}=\operatorname{Max}|f(z)-S(z)|$,

$L_{\text {tabel }}=L_{(\alpha, n)}$

Dengan hipotesis :

$H_{0} \quad$ : Data mengikuti sebaran normal.

$H_{1}$ : Data tidak mengikuti sebaran normal.

Kesimpulan : jika $L_{\text {hitung }} \leq L_{\text {tabel }}$, maka $H_{0}$ diterima.

b. Uji Homogenitas

Pengujian homogenitas merupakan pengujian berkenaan dengan sama tidaknya variansivariansi dua buah distribusi atau 
lebih. Dalam hal ini uji homogenitas yang hendak digunakan adalah uji Bartlett. Uji Bartlett dapat dimanfaatkan untuk menguji suatu homogenitas dari 2 kelompok data ataupun lebih. Rumus uji Bartlett yang digunakan adalah :

$$
\begin{gathered}
X_{\text {hitung }}^{2}=\ln (10)\left\{B-\sum_{i=1}^{k} d k \log S^{2}\right\} \\
X_{\text {tabel }}^{2}=X^{2}{ }_{(\alpha, k-1)}
\end{gathered}
$$

Hipotesis dari uji Bartlett sebagai berikut:

$H_{0}$ : Data Homogen
$H_{1}$ : Data tidak Homogen

Penarikan kesimpulan untuk uji Bartlett memiliki kriteria sebagai berikut :

Jika $X_{\text {hitung }}^{2} \leq X_{\text {tabel }}^{2}$, maka $H_{0}$ diterima. (Novalia and Syazali 2014)

Setelah uji prasyarat terpenuhi, selanjutnya analisis data uji hipotesis dilakukan dengan menggunakan uji ANAVA klasifikasi 2 arah dengan rumus pada Tabel 2 berikut:

Tabel 2.

Tabel Anova Klasifikasi Dua Arah

\begin{tabular}{cccccc}
\hline Sumber Keragaman & $\mathbf{d b}$ & $\mathbf{J K}$ & $\mathbf{K T}$ & $\boldsymbol{F}_{\boldsymbol{h i t}}$ & $\boldsymbol{F}_{\text {tab }}$ \\
Baris (B) & $b-1$ & $J K_{B}$ & $K T_{B}=\frac{J K_{B}}{d b_{B}}$ & $\frac{K T_{B}}{K T_{G}}$ & $F_{B}$ \\
Kolom (K) & $k-1$ & $J K_{K}$ & $K T_{K}=\frac{J K_{K}}{d b_{K}}$ & $\frac{K T_{K}}{K T_{G}}$ & $F_{K}$ \\
Interaksi (I) & $(b-1)(b-1)$ & $J K_{I}$ & $K T_{A B}=\frac{J K_{I}}{d b_{I}}$ & $\frac{K T_{I}}{K T_{G}}$ & $F_{I}$ \\
Galat & $b k(n-1)$ & $J K_{G}$ & $K T_{G}$ & & \\
Total & $b k n-1$ & $J K_{T}$ & &
\end{tabular}

Kesimpulan setelah pengujian apabila $F_{\text {hitung }}>F_{\text {tabel }}$ maka $H_{0}$ ditolak.

Keterangan:

$J K_{K} \quad$ : Jumlah Kuadrat Kolom

$J K_{B} \quad$ : Jumlah Kuadrat Baris

$J K_{I} \quad$ : Jumlah Kuadrat Interaksi

$J K_{G} \quad$ : Jumlah Kuadrat Galat

$J K_{T} \quad$ : Jumlah Kuadrat Total

$K T_{B} \quad$ : Kuadrat Tengah Baris

$K T_{K} \quad$ : Kuadrat Tengah Kolom

$K T_{G} \quad$ : Kuadrat Tengah Galat

$K T_{A B}$ : Kuadrat Tengah Interaksi (Novalia and Syazali 2014)

Prosedur dalam pengujian menggunakan analisis variansi dua jalan yaitu :

\section{Hipotesis Pertama}

$$
\begin{array}{ll}
H_{0 A} & : \alpha_{1}=\alpha_{2} \text { (tidak terdapat } \\
& \text { pengaruh efek antar baris } \\
& \text { terhadap variable terikat) } \\
H_{1 A} & : \alpha_{1} \neq \alpha_{2} \text { (terdapat pengaruh } \\
& \text { efek antar baris terhadap } \\
& \text { variable terikat) }
\end{array}
$$

$\alpha_{1}$ : pembelajaran matematika dengan aktivitas quick on the draw dalam tatanan pembelajaran kooperatif ditinjau dari self confidence

$\alpha_{2}$ : pembelajaran matematika dengan model konvensional

2. Hipotesis Kedua

$H_{0 B}: \beta_{1}=\beta_{2}=\beta_{3}$ (tidak terdapat pengaruh efek antar kolom terhadap variabel terikat)

$H_{1 B}: \beta_{1} \neq 0$ (terdapat pengaruh efek antar kolom terhadap variabel terikat)

Keterangan :

$\beta_{1}$ : Self confidence tinggi

$\beta_{2}$ : Self confidence sedang

$\beta_{3}$ : Self confidence rendah

$j: 1,2,3$

\section{Hipotesis Ketiga}

$H_{0 A B} \quad:(\alpha \beta)_{i j}=0$ untuk setiap $\mathrm{i}=1$, 2 dan $\mathrm{j}=1,2,3$ (tidak terdapat

Keterangan : 


\section{interaksi baris dan kolom terhadap variabel terikat) \\ $H_{1 A B} \quad:(\alpha \beta)_{i j}=$ paling sedikit ada satu pasang $(\alpha \beta)_{i j}$ (terdapat interaksi baris dan kolom terhadap variabel terikat)}

\section{HASIL DAN PEMBAHASAN}

Tes hasil belajar matematika pada penerapan aktivitas quick on the draw dalam tatanan pembelajaran kooperatif. Adapun hasil deskriptif data tes hasil belajar disajikan pada Tabel 3 .

Tabel 3. Hasil Deskriptif Data Tes Hasil Belajar

\begin{tabular}{cccc}
\hline \multicolumn{2}{c}{ Kelas Eksperimen } & \multicolumn{2}{c}{ Kelas Kontrol } \\
$\boldsymbol{X}_{\text {maks }}$ & 100 & $\boldsymbol{X}_{\text {maks }}$ & 100 \\
$\boldsymbol{X}_{\boldsymbol{m} \text { min }}$ & 52.21 & $\boldsymbol{X}_{\boldsymbol{m} \text { in }}$ & 41.912 \\
$\overline{\boldsymbol{X}}$ & 78.3422 & $\overline{\boldsymbol{X}}$ & 71.22549 \\
$\mathrm{Me}$ & 77.206 & $\mathrm{Me}$ & 70.588 \\
$\mathrm{Mo}$ & 100 & Mo & 70.588 \\
\hline
\end{tabular}

Tabel 3 diatas menunjukkan deskriptif data dari hasil penerapan aktivitas quick on the draw dalam tatanan pembelajaran kooperatif terhadap hasil belajar. Dari deskriptif data tersebut diperoleh nilai hasil maksimum, minimum, variance, mean dan modus. Hasil analisis data diperoleh skor maksimum kelas eksperimen adalah 100 sedangkan skor maksimum kelas kontrol adalah 100. Skor minimum kelas eksperimen adalah 52.21 sedangkan skor minimum kelas kontrol adalah 41.912. Skor variance kelas eksperimen adalah 78.3422 sedangkan skor variance kelas kontrol adalah 71.22549. Skor mean kelas eksperimen adalah 77.206 sedangkan skor mean kelas kontrol adalah 70.588. Skor modus kelas eksperimen adalah 100, sedangkan skor modus kelas kontrol adalah 70.588. Berdasarkan deskriptif data diatas menunjukkan bahwa skor minimum, variance, mean dan modus pada kelas eksperimen lebih besar daripada skor pada kelas kontrol. Namun pada hasil skor maksimum dari kedua model menghasilkan nilai skor yang sama besar 100.

Tes angket self confidence pada penerapan aktivitas quick on the draw dalam tatanan pembelajaran kooperatif. Adapun hasil deskriptif data tes hasil belajar disajikan pada Tabel 4 .

Tabel 4. Hasil Deskriptif Data

Tes Angket self confidence

\begin{tabular}{cccc}
\multicolumn{2}{c}{ Kelas Eksperimen } & \multicolumn{2}{c}{ Kelas Kontrol } \\
$\boldsymbol{X}_{\text {maks }}$ & 91 & $\boldsymbol{X}_{\text {maks }}$ & 86 \\
$\boldsymbol{X}_{\boldsymbol{m} \text { in }}$ & 65 & $\boldsymbol{X}_{\text {min }}$ & 49 \\
$\overline{\boldsymbol{X}}$ & 81.51515 & $\overline{\boldsymbol{X}}$ & 67.9 \\
Me & 81 & Me & 68 \\
Mo & 80 dan 90 & Mo & 62,66 dan 69 \\
\hline
\end{tabular}

Tabel 4 diatas menunjukkan deskriptif data dari hasil penerapan aktivitas quick on the draw dalam tatanan pembelajaran kooperatif ditinjau dari self confidence. Dari deskriptif data tersebut diperoleh nilai hasil maksimum, minimum, variance, mean dan modus. Hasil analisis data diperoleh skor maksimum kelas eksperimen adalah 91 sedangkan skor maksimum kelas kontrol adalah 86. Skor minimum kelas eksperimen adalah 65 sedangkan skor minimum kelas kontrol adalah 49. Skor variance kelas eksperimen adalah 81.51515 sedangkan skor variance kelas kontrol adalah 67.9. Skor mean kelas eksperimen adalah 81 sedangkan skor mean kelas kontrol adalah 68. Skor modus kelas eksperimen adalah 80 dan90 sedangkan skor modus kelas kontrol adalah 62, 66 dan 69 . Berdasarkan deskriptif data diatas menunjukkan bahwa skor minimum, variance, mean dan modus pada kelas eksperimen lebih besar daripada skor pada kelas kontrol.

Sebelum melakukan uji ANAVA dua jalan sel tak sama terlebih dahulu dilakukan uji asumsi diantaranya uji normalitas dan uji homogenitas untuk mengetahui apakah sebaran data berdistribusi normal atau tidak dan uji homogenitas untuk mengetahui sama tidaknya variansi dua buah distribusi 
Desimal, 1 (3), 2018 - 280

Siti Maimunah, Sri Purwanti Nasution

data. Adapun hasil data uji normalitas dapat dilihat pada Tabel 5

Tabel 5. Hasil Uji Normalitas Tes Hasil Belajar

\begin{tabular}{lccl}
\multicolumn{1}{c}{ Kelas } & $\boldsymbol{L}_{\text {hitung }}$ & $\boldsymbol{L}_{\text {tabel }}$ & Kesimpulan \\
Eksperimen & 0.1456 & 0.1518 & Normal \\
Kontrol & 0.1295 & 0.1590 & Normal \\
\hline
\end{tabular}

Tabel 5 diatas menunjukkan hasil uji normalitas terhadap hasil belajar matematika pada aktivitas quick on the draw dalam tatanan pembelajaran kooperatif dengan taraf signifikasi $\alpha=0.05$. Berdasarkan hasil data uji normalitas pada kelas eksperimen diperoleh $\quad L_{\text {hitung }}=0.14564$ dan $L_{\text {tabel }}=0.1518$. sedangkaan pada kelas kontrol diperoleh $L_{\text {hitung }}=0.1295$ dan $L_{\text {tabel }}=0.1590$. Sebaran data dikatakan berdistribusi normal jika $L_{\text {hitung }}<L_{\text {tabel }}$. Kemampuan representasi matematis pada kelas eksperimen diperoleh $L_{\text {hitung }}<L_{\text {tabel }}=0.1456<0.1518$ dan pada kelas kontrol $L_{\text {hitung }}<L_{\text {tabel }}=$ 0.1295 dan $<0.1590$. Artinya sebaran data berdistribusi normal.

Uji homogenitas terhadap hasil belajar pada aktivitas quick on the draw dalam tatanan pembelajaran kooperatif berdasarkan hasil deskriptif data pada aktivitas quick on the draw dalam tatanan pembelajaran kooperatif diperoleh $F_{\text {hitung }}=1.64185294$. Variansi dua buah data dikatakan homogen jika $F_{\text {hitung }}<$ $F_{\text {tabel }}=1.64185294<3.841 \quad$ Artinya data berasal dari distribusi normal dan homogen.

\section{Tabel 6. Hasil Uji Normalitas Tes Angket Self Confidence}

\begin{tabular}{cccc}
\hline Kelas & $\boldsymbol{L}_{\text {hitung }}$ & $\boldsymbol{L}_{\text {tabel }}$ & Kesimpulan \\
Eksperimen & 0.1404 & 0.1518 & Normal \\
\hline
\end{tabular}

\begin{tabular}{llll}
\hline Kontrol & 0.1131 & 0.1590 & Normal \\
\hline
\end{tabular}

Tabel 6 diatas menunjukkan hasil uji normalitas ditinjau dari self confidence pada aktivitas quick on the draw dalam tatanan pembelajaran kooperatif dengan taraf signifikasi $\alpha=0.05$. Berdasarkan hasil data uji normalitas pada kelas eksperimen diperoleh $L_{\text {hitung }}=$ 0.1404 dan $L_{\text {tabel }}=0.1518$ sedangkaan pada kelas kontrol diperoleh $L_{\text {hitung }}=$ 0.1131 dan $L_{\text {tabel }}=0.1590$. Sebaran data dikatakan berdistribusi normal jika $L_{\text {hitung }}<L_{\text {tabel }}$. Kemampuan representasi matematis pada kelas eksperimen diperoleh $L_{\text {hitung }}<L_{\text {tabel }}=$ $0.14042<0.1518$ dan pada kelas kontrol $L_{\text {hitung }}<L_{\text {tabel }}=0.1131$ dan $<0.1590$.

Artinya sebaran data berdistribusi normal.

Uji homogenitas terhadap hasil belajar pada aktivitas quick on the draw dalam tatanan pembelajaran kooperatif berdasarkan hasil deskriptif data pada aktivitas quick on the draw dalam tatanan pembelajaran kooperatif diperoleh $F_{\text {hitung }}=3.646068715$. Variansi dua buah data dikatakan homogen jika $F_{\text {hitung }}<F_{\text {tabel }}=3.646068715<3.841$ Artinya data berasal dari distribusi normal dan homogen.

Uji syarat asumsi kenormalan dan kehomogenan sudah terpenuhi sehingga dapat dilakukan uji statistik parametik yaitu uji ANAVA dua jalan sel tak sama. Uji ANAVA dua jalan sel tak sama dilakukan untuk menguji hipotesis, dengan taraf signifikan yang digunakan adalah 5\%, dimana uji hipotesis tersebut digunakan untuk menjawab pertanyaan dari rumusan masalah. 
Desimal, 1 (3), 2018 - 281

Siti Maimunah, Sri Purwanti Nasution

Tabel 7.

Rangkuman Analisis Variansi Dua Jalan Sel Tak Sama

$\begin{array}{ccccccc}\begin{array}{c}\text { Sumber } \\ \text { Keragaman }\end{array} & \text { JK } & \text { Db } & \text { KT } & \text { F hit } & \text { F tab } & \text { Kesimpulan } \\ \text { Baris } & 11460.47318 & 2,000 & 5730.236591 & 70.95287247 & 3.156 & H_{0} \text { Di Tolak } \\ \text { Kolom } & 795.8907223 & 1,000 & 795.8907223 & 9.854869345 & 4.007 & H_{0} \text { Di Tolak } \\ \text { Interaksi } & -70.13877485 & 2,000 & -35.0693874 & -0.43423578 & 3.156 & H_{0} \text { Di Terima } \\ \text { Galat } & 4603.386365 & 57,000 & 80.76116429 & & & \\ \text { Total } & 16789.61149 & 62,000 & & & & \end{array}$

Berdasarkan Tabel 7 perhitungan ANAVA dua jalan dengan sel tak sama diperoleh hasil uji bahwa: (1) harga statistik F hit $=70.95287247$ dan $\mathrm{F}$ tab $=$ 3.156 menyatakan bahwa $\mathrm{F}$ hit $>\mathrm{F}$ tab, sehingga dapat ditarik kesimpulan $\boldsymbol{H}_{\mathbf{0}} \mathbf{D i}$ Tolak. (2) harga statistik $\mathrm{F}$ hit $=9.8548$ 69345 dan $\mathrm{F}$ tab $=4.007$ menyatakan bahwa $\mathrm{F}$ hit $>\mathrm{F}$ tab, hal ini berarti bahwa $\boldsymbol{H}_{\mathbf{0}}$ Di Tolak. (3) harga statistik F hit = 0.43423578 dan $\mathrm{F}$ tab $=3.156$, dengan demikian $\mathrm{F}$ hit $<\mathrm{F}$ tab, yang berarti bahwa $\boldsymbol{H}_{\mathbf{0}}$ Di Terima.

Berdasarkan pemaparan hasil dari penelitian ini dapat disimpulkan bawa aktivitas quick on the draw dapat mempengaruhi hasil belajar, self confidence dapat mempengaruhi hasil belajar serta tidak ada interaksi antara aktivitas quick on the draw dengan self confidence terhadap hasil belajar. Hasil penelitian ini terdapat kesamaan dengan penelitian terdahulu yaitu aktivitas quick on the draw efektif untuk digunakan dalam pembelajaran. Terbukti bahwa penggunaan aktivitas quick on the draw menunjukkan bahwa adanya pengaruh pengaruh terhadap hasil belajar. Hal ini dapat

dilihat dari penelitian tersebut bahwa aktivitas quick on the draw dapat meningkatkan hasil belajar peserta didik yang sesuai dengan analisis uji-t data pretest-posttest hasil belajar siswa kelompok eksperimen yang diperoleh thitung sebesar $-11,481$, df $=29$, dan $p$ sebesar 0,000. Nilai p lebih kecil dari taraf signifikansi 5\%. (Virgiantoro 2017)
Perbedaan dengan penelitian sebelumnya adalah peneliti menggunakan aktivitas quick on the draw dalam tatanan pembelajaran kooperatif yang ditinjau dari self confidence terhadap hasil belajar, sedangkan penelitian sebelumnya menggunakan aktivitas quick on the draw untuk meningkatkan kemandirian belajar dan hasil belajar. Hasil dari penelitian yang dilakukan oleh peneliti adalah sebagai berikut: (1) F hit $=70.95287247$ $>\mathrm{F}$ tab $=3.156$, hal ini berarti bahwa aktivitas quick on the draw dalam tatanan pembelajaran kooperatif berpengaruh kepada hasil belajar peserta didik. (2) F hit $=9.854869345>\mathrm{F}$ tab $=4.007$, dengan demikian hal tersebut memiliki arti bahwa peserta didik yang memiliki kategori self confidence (tinggi, sedang, rendah) memiliki pengaruh terhadap hasil belajar peserta didik. (3) $\mathrm{F}$ hit = $0.434235783<\mathrm{F}$ tab $=3.156$, maka dengan demikian tidak terdapat interaksi antara aktivitas quick on the draw dalam tatanan pembelajaran kooperatif dengan self confidence terhadap hasil belajar peserta didik.

Aktivitas quick on the draw yang berpengaruh terhadap hasil belajar peserta didik menuntut peserta didik untuk dapat menemukan solusi dari permasalahan yang ada, yang disedakan dalam sebuah kartu permainan. Dalam hal ini langkah-langkah aktivitas quick on the draw yang berpengaruh terhadap hasil belajar yaitu terdapat pada langkah pembelajaran ke 4-7, dimana peserta didik menerima permasalahan yang ada dalam kartu permainan dan guru 
Desimal, 1 (3), 2018 - 282

Siti Maimunah, Sri Purwanti Nasution

memberikan petunjuk serta arahan tentang bagaimana cara menyelesaikannya melalui kegiatan diskusi, beradu kecepatan dan berlomba dengan kelompok lain untuk menjadi kelompok pemenang (Ginnis 2008).

Sehingga hal ini sejalan dengan hasil analisis data penelitian bahwasannya: 1) terdapat pengaruh aktivitas quick on the draw dalam tatanan pembelajaran kooperatif terhadap hasil belajar; 2) peserta didik yang memiliki kategori self confidence (tinggi, sedang, rendah) terhadap hasil belajar berpengaruh. Akan tetapi terdapat hasil analisis data yang tak sejalan yakni pada hipotesis 3) tidak adanya interaksi antara aktivitas quick on the draw dalam tatanan pembelajaran kooperatif dengan self confidence terhadap hasil belajar.

\section{SIMPULAN DAN SARAN}

Berdasarkan hasil analisis dan pengolahan data yang didukung dengan landasan teori serta mengacu pada tujuan penelitian, maka dapat disimpulkan bahwa: Berdasarkan hasil analisis data pada hipotesis ke-1 (baris) diperoleh $\mathrm{F}$ hit $=70.95287247>\mathrm{F} \mathrm{tab}=3.156$, hal dalam tatanan pembelajaran kooperatif berpengaruh kepada hasil belajar peserta didik. Sesuai dengan hasil analisis data pada hipotesis ke-2 (kolom), maka diperoleh $\mathrm{F}$ hit $=9.854869345>\mathrm{F}$ tab $=$ 4.007, dengan demikian hal tersebut memiliki arti bahwa peserta didik yang memiliki kategori self confidence (tinggi, sedang, rendah) memiliki pengaruh terhadap hasil belajar peserta didik. Berdasarkan hasil analisis data pada hipotesis ke-3 (interaksi) diperoleh $\mathrm{F}$ hit $=-0.434235783<\mathrm{F}$ tab $=3.156$, maka dengan demikian tidak terdapat interaksi antara aktivitas quick on the draw dalam tatanan pembelajaran kooperatif dengan self confidence terhadap hasil belajar peserta didik.
Berdasarkan kesimpulan diatas terdapat bebrapa saran diantaranya: untuk penelitian selanjutnya dapat mencari aktivitas pembelajaran yang lain agar dapat menumbuhkan self confidence peserta didik sehingga memiliki pengaruh yang lebih baik terhadap hasil belajar matematika. Semoga penelitian ini dapat bermanfaat dan menjadi sumber rujukan ataupun referensi untuk penelitian selanjutnya.

\section{DAFTAR PUSTAKA}

Ahriani, Faridha. 2013. "Pengaruh Model Pembelajaran Kooperatif Dan Gaya Belajar Terhadap Hasil Belajar Kimia Peserta Didik Kelas X SMK Negeri 2 Bantaeng." Jurnal Chemica 14 (1): 19.

Amalia, Yuli, M Duskri, and Anizar Ahmad. 2015. "Penerapan Model Eliciting Activities Untuk Meningkatkan Kemampuan Berpikir Kreatif Matematis Dan Self Confidence Siswa SMA." Jurnal Didaktik Matematika 2 (2): 38-48.

Anwar, Chairul. 2016. "The Effectiveness of Problem Based Learning Integrated With Islamic Values Based on ICT on Higher Order Thinking Skill and Students' Character." Al-Ta Lim Journal 23 (3): 224-31.

Ariawan, Rezi. 2016. "Pengaruh Pembelajaran Visual Thinking Disertai Aktivitas Quick on the Draw Terhadap Kemampuan Komunikasi Matematis Siswa" 2 (1): 20-30.

———. 2017. "Pengaruh Pembelajaran Visual Thinking Disertai Aktivitas Quick on the Draw Terhadap Kemampuan Pemecahan Masalah Dan Komunikasi Matematis." JPPM 10 (1): 1-16.

Cahyani, I Gusti Agung Ayu Novia, I Made Tegeh, and I Komang Sudarma. 2015. "Pengaruh Model Pembelajaran Kooperatif Tipe Stad Berbantuan Multimedia Pembelajaran Terhadap 
Hasil Belajar Pkn." E-Journal Edutech Universitas Pendidikan Ganesha 3 (1).

Dewi, Pande Putu Yustika, IB Surya Manuaba, and Ni Wayan Suniasih. 2017. "Pengaruh Model Pembelajaran Group Investigation Berbasis Proyek Terhadap Hasil Belajar IPA Siswa Kelas IV." International Journal of Elementary Education 1 (4): 264-71.

Fadholi, T., Waluya, B., \& Mulyono. 2015. "Analisis pembelajaran Matematika dan kemampuan literasi serta karakter siswa SMK." Unnes Journal of Mathematics Education Research 4 (1): 42-48.

Fitri, R., Helma, \& Syarifuddin, H. 2014. "Penerapan Strategi The Firing Line pada Pembalajaran Matematika Siswa Kelas XI IPS SMA Negeri 1 Batipuluh." Jurnal Pendidikan Matematika 3 (1): 18-22.

Fitriasari, P. 2017. "Pemanfaatan Software Geogebra Dalam Pembelajaran Matematika. Jurnal Pendidikan Matematika RAFA 3 (1), 57-69.

Ginnis, Paul. 2008. Trik Dan Taktik Mengajar (Strategi Meningkatkan Dan Pencapaian Pengajaran Di Kelas). Indonesia: Macanan Jaya Cemerlang.

Gumay, Ovilia Putri Utami, Eti Kodarsih, and Ahmad Budi Mulyanto. 2016. "Pengaruh Model Pembelajaran Kooperatif Tipe Student Teams Achievement Division (STAD) Terhadap Hasil Belajar Fisika Siswa Kelas X SMA Negeri 2 Muara Beliti Tahun Pelajaran 2015/2016." Prosiding Seminar Nasional Fisika (EJournal) 5: 39-44..

Haeruman, Leny Dhianti, Wardani Rahayu, and Lukita Ambarwati. 2017. "Pengaruh Model Discovery Learning Terhadap Peningkatan Kemampuan Berpikir Kritis Matematis Dan Self Confidence Ditinjau Dari Kemampuan Awal
Matematis Siswa SMA Di Bogor Timur." JPPM 10 (2): 157-68.

Insany, Yenni Agustine Shovia. 2016. "Pengaruh Model Pembelajaran Kooperatif Tipe Jigsaw Terhadap Prestasi Belajar Siswa Pada Pelajaran Fisika SMK." Jurnal Pemikiran Penelitian Pendidikan Dan Sains 4 (1): 73-77.

Islami, R. Ahmad Zaky El, Nahadi, and Anna Permanasari. 2015. "Membangun Kepercayaan Diri Siswa Pada Konsep Asam Basa Melalui Pembelajaran Inkuiri Terbimbing." EDUSAINS 7 (1): 64-69. Lestiyaningsih, Herdika, Hobri, and Arika Indah. 2013. "Penerapan Pembelajaran Quick On The Draw Untuk Meningkatkan Hasil Belajar Matematika Pada Sub Pokok Bahasan Aritmetika Sosial Siswa Kelas VII F Semester Ganjil SMP Negeri 10 Jember Tahun Ajaran 2012/2013." Kadikma 4 (2): 39-48.

Mardiyanti, Ika. 2016. "Pengaruh Model Cooperatif Learning Tipe Jigsawterhadap Hasil Belajarmata Kuliah Penanganan Kegawatdaruratan Pada Mahasiswa Semester V." Jurnal Ilmiah Kesehatan 9 (1): 58-68.

Muthoharoh, Siti, and Benedictus Kusmanto. 2015. "Upaya Meningkatkan Motivasi Dan Prestasi Belajar Matematika Dengan Quick On The Draw Siswa Kelas X Teknik Instalasi Tenaga Listrik A SMK Negeri 1Sedayu." Jurnal Pendidikan Matematika 3 (3): 257-64.

Novalia, and Muhamad Syazali. 2014. Olah Data Penelitian Pendidikan. Bandar Lampung: Anugrah Uutama Raharja: 2014.

Purwasih, Ratni. 2015. "Peningkatan Kemampuan Pemahaman Matematis dan Self Confidence Siswa MTs di Kota Cimahi Melalui Model Pembelajaran Inkuiri Terbimbing." Jurusan Pendidikan Matematika, 
Desimal, 1 (3), 2018 - 284

Siti Maimunah, Sri Purwanti Nasution

STKIP Siliwangi Bandung 9 (1): 1625.

Rosyana, Tina, and Indah Puspita Sari. 2015. "Penerapan Aktivitas Quick On The Draw Melalui Pendekatan Thinking Aloud Pair Problem Solving Untuk Meningkatkan Kemampuan Komunikasi Dan Penalaran Matematis Siswa MA." Jurnal Ilmiah UPT P2M STKIP Siliwangi 2 (2): 192202.

Sari, Nadlifa Meiliya, and Novy Eurika. 2016. "Penerapan Model Pembelajaran Group Investigation Untuk Meningkatkan Hasil Belajar Siswa." Jurnal Biologi Dan Pembelajaran Biologi 1 (1): 29-41.

Silvina, Rini. 2017. "Pengaruh Model Pembelajaran Kooperatif Tipe Think Pair Share (Tps) Dan Kemampuan Awal Terhadap Hasil Belajar Biologi Siswa Kelas Viii Smpn 38 Sijunjung." Jurnal Pendidikan Rokania 2 (2):
265-73.

Sugiyono. 2010. Metode Penelitian Pendidikan Pendekatan Kuantitatif, Kualitatif, Dan R\&D. Bandung: Alfabeta.

Syafitri, Qurnia, Mujib, Chairul Anwar, Netriwati, and Wawan. 2018. "The Mathematics Learning Media Uses Geogebra on the Basic Material of Linear Equations." Al- Jabar: Jurnal Pendidikan Matematika 9 (1): 9-18.

Virgiantoro, Eric Vernando. 2017. "Efektivitas Model Pembelajaran Kooperatif Learning Tipe Quick On The Draw Untuk Meningkatkan Kemandirian Belajar Dan Hasil Belajar Siswa Kelas X Pada Mata Pelajaran Ekonomi Di SMAN 1 Tempel Tahun Ajaran 2015/2016." Jurnal Pendidikan Ekonomi 6 (3): 259-66. 